"Sustainability reporting in the light of corporate social responsibility development: economic and legal issues"

\begin{tabular}{|c|c|}
\hline & Victor Sukhonos (D) https://orcid.org/0000-0001-5520-0227 \\
\hline AUTHORS & $\begin{array}{l}\text { Inna Makarenko (D https://orcid.org/0000-0001-7326-5374 } \\
\text { R http://www.researcherid.com/rid/AAE-8453-2020 }\end{array}$ \\
\hline
\end{tabular}

Victor Sukhonos and Inna Makarenko (2017). Sustainability reporting in the light ARTICLE INFO $\quad \begin{aligned} & \text { of corporate social responsibility development: economic and leg } \\ & \text { Problems and Perspectives in Management, 15(1-1), 166-174. }\end{aligned}$ doi:10.21511/ppm.15(1-1).2017.03

DOI http://dx.doi.org/10.21511/ppm.15(1-1).2017.03

RELEASED ON

Wednesday, 10 May 2017

RECEIVED ON

Wednesday, 01 February 2017

ACCEPTED ON

Saturday, 15 April 2017

$((c)$ EY-No

LICENSE

This work is licensed under a Creative Commons Attribution-NonCommercial 4.0 International License

JOURNAL

"Problems and Perspectives in Management"

ISSN PRINT 1727-7051

ISSN ONLINE

$1810-5467$

PUBLISHER

LLC "Consulting Publishing Company "Business Perspectives"

FOUNDER

LLC "Consulting Publishing Company "Business Perspectives"

NUMBER OF REFERENCES

20
NUMBER OF FIGURES

3
NUMBER OF TABLES

1

C The author(s) 2023. This publication is an open access article. 
Victor Sukhonos (Ukraine), Inna Makarenko (Ukraine)

\title{
Sustainability reporting in the light of corporate social responsibility development: economic and legal issues
}

\begin{abstract}
Independent audit assurance of sustainability reporting is the basis for increasing the credibility of the stakeholders, its transparency and reliability; it is a means of implementing legal liability of the company and the evidence of achievement of its legitimacy to the public. The bases for providing such assurance are the standards of implementation of audit tasks in the sphere of sustainable development. Comparative analysis of international practice as for assurance regarding the SR with local realities, based on the reporting database of Ukrainian GRI companies for the 2005-2014 years, witnessed the initial phase of such practices among Ukrainian companies and the need to strengthen regulatory efforts to determine the legal status of SR auditing standards in Ukraine, ensuring a legal environment and the development of corporate social responsibility initiatives.
\end{abstract}

Keywords: sustainability reporting, assurance, corporate social responsibility, legitimacy theory, legal status, legal responsibility.

JEL Classification: G02, G14, M41.

Received on: $1^{\text {st }}$ of February, 2017.

Accepted on: $15^{\text {th }}$ of April, 2017.

\section{Introduction}

The information quintessence of initiatives on corporate social responsibility (CSR) of companies is their disclosed reporting on sustainable development (SR), and a sign of legitimacy and recognition by society is an independent assurance of such reports.

The primary objective of assurance on SR, in addition to providing accurate information in decision making of stakeholders and improving the management of a company, appears matching SR of the company with legal compliance requirements and independent certification of its credibility as a means of achieving legitimacy.

Using the most common standard of audit assurance SR AA1000 Assurance Standard (AA1000AS) from Accountability and ISAE 3000 Assurance Engagements Other Than Audits or Reviews of Historical Financial Information from the IAASB, which are complementary, today requires critical reflection due to the increase in SR, complexity of its indicators, seeking new ways to achieve legitimacy of companies to respond to new information requests of society and stakeholders.

The term "assurance" in the interpretation of International Federation of Accountants (IFAC) means auditing task, in which a practitioner expresses a conclusion designed to enhance the degree of confidence of the intended users other than the responsible party about the outcome of the evaluation or measurement.

(C) Victor Sukhonos, Inna Makarenko, 2017.

Victor Sukhonos, Sumy State University, Ukraine.

Inna Makarenko, Sumy State University, Ukraine.

This is an Open Access article, distributed under the terms of the Creative Commons Attribution-NonCommercial 4.0 International license, which permits re-use, distribution, and reproduction, provided the materials aren't used for commercial purposes and the original work is properly cited.
The most famous initiative in the field of SR formation - Global Reporting Initiative (GRI) uses the term "external assurance" to refer to a wide range of approaches to assess the report on sustainable development.

In this regard, not only SR, which is widely spread in the world with a view to the adoption of Sustainable Development Goals (SDG 2.16), needs to determine the accuracy of the data, to ensure their quality, but also the very assurance process requires the formation of a single legal framework.

A particular import ance in achieving legal compliance of SR and its assurance for Ukrainian companies gets in the context of the requirements of the Association Agreement with the EU, which, firstly, requires changes in national systems ofaccounting and auditing. Secondly, the institution of quality assurance of SR disclosure requires radical changes with the spread of European business practices on national basis as a means of achieving their legitimate business models that meet stakeholder requests for information, promotion on foreign markets.

The purpose of the research is the comparative analysis of experience of providing audit assurance on SR in national and international practice in the light of the theory of legitimacy.

Implementation peculiarities of SR assurance in Ukraine are problematic, because the processes of drafting such statements and its certification have no branched regulatory settlement. Comparing international practice of assurance regarding SR with Ukrainian realities, based on the reporting database of Ukrainian GRI companies for the years 20052014 showed initial stage of its development and the dominance of large audit firms in the market as providers of such assurance. 
There are variables in providing SR assurance of Ukrainian companies due to regulatory requirements proper standards of such assurances, actors (recipients and providers of assurance), the object (scale) of research, a way of expression a thought about assurance.

However, the use of standards on IFAC assurance as national standards, as well as relevant breach of their use in Ukraine, which suggests Ukraine as a country with a weak legal environment, are poorly researched.

It should be noted that the results correspond with the findings, made by Perego (2009) as for the recognition of large auditing firms as the main providers of assurance in countries with weak legal environment.

Achieving absolute benefits of SR assurance by Ukrainian companies such as ensuring the legitimacy of the company activities, increase of its recognition by society, trust and reliability, value for stakeholders and enhancing communication with them, quality of reporting for strategic decision-making by the heading board of the company and improving its management, as well as reducing information risks and asymmetry regarding the company on the financial markets, should be based on clear and understandable legal basis for its implementation.

The remainder of the paper is structured as follows. Section 1 provides literature and legislative review of SR assurance and its role in seeking legitimacy. Section 2 provides practical insights in SR assurance in Ukraine and all over the world. Section 3 explores out lines of future implication of SR assurance in Ukraine. Final section concludes with a discussion of the issues raised.

\section{Literature review}

The key idea in the understanding of CSR is the fact that business and society are interconnected through a delegation of power to the latter by establishing certain rules, standards and regulations (legal liability), accountability mechanisms that are disclosed in the SR, quality and trust level, to which is confirmed by auditors. The sign of business power recognition is its legitimacy to the public.

In academic circles, the role of legal responsibility of business as part of its CSR has been studied for a long time and is determined at the level of «laws» and corresponding principles. In particular «the iron law of responsibility» (Davis, 1973)) emphasizes that in the long run those companies that do not use the power in such a direction that society considers responsible, will lose this power. This power is the result not only of possible use of available resources, but also the delegated by the state and society through regulations and standards of business practices powers. These documents are intended to reflect the interests of stakeholders in the implementation of business models of companies in a responsible manner.
This law is one of the fundamental principles of CSR by Wood (1991) - The Principle of Legitimacy. Along with The Principle of Public Responsibility, which postulates that businesses are responsible for outcomes, related to their primary and secondary areas of involvement with society, Preston \& Post (1975), Carroll (1979) justify that the basis for achieving CSR is the meeting economic, legal, ethical and discretionary expectations of society concerning business operations in a specified time.

This approach makes up the importance of the legal aspect of CSR because of the legal component in its structure. In particular, Carroll (1991) in the CSR pyramid after the economic responsibility assigns a prominent place to legal responsibility of companies as a following the laws of society that determine, what is good and what is bad and sets the "rules of the game." The development of approaches to structuring previous CSR pyramid allowed to form a cross-domain model (Doherty, 2009) with a definition of economic-legal and ethical-legal responsibility of business.

For countries, developing in the CSR model, justified by Visser (2006), the legal responsibility means matching the company activities with requirements of the official governmental bodies.

Despite the existence of different views on the structure of CSR and the place of legal responsibility in it, its detailed analysis is embodied in a separate line of research, combined by the theory of legitimacy which is derived from the theory of "social contract" between business and society (Deegan, 2002; O' Donovan, 2002; Deegan and Unerman 2011). Through CSR mechanisms and their disclosure companies try to legitimize their activities, to demonstrate the level of legal liability, to get approval of society, thus creating the basis for further implementation of powers. In terms of meeting the information needs of different groups of stakeholders via CSR disclosure as a means of achieving legitimacy by companies the following works should be mentioned: Maignan and Ralston (2002), Adams et al., (1998), Margolis and Walsh (2003), Roberts (1992), Branco and Rodrigues (2008), Bayoud et al. (2012). Omran (2015) is proved that the theory of legitimacy is the basis for disclosure of CSR in SR in developed countries, while the social contract theory is more peculiar to developing countries (emerging economy).

A separate line consists of works, studying the role of CSR assurance as a means of achieving the legitimacy of companies. The importance of this area of research is caused by widespread of SR in recent years and ensuring its reliability, accuracy, transparency, and compliance to the demands of society and other stakeholders (Adams and Evans, 2004; Adams et al., 1998; Adams, 2004). 
Along with understanding of the SR assurance as a means of ensuring the legitimacy of the company, managing tool of relations with stakeholders or the process of creating a good impression (Spence and Gray, 2007), the practice of reporting assurance is seen as a communication mechanism that increases the reliability of reporting (Deegan, Cooperr \& Shelly, 2006), as a means of improving the quality of information on sustainable development and confidence of stakeholders (Simnett, Vanstraelen \& Chua, 2009).

In the last work the authors conclude that companies located in countries with stakeholder model and a more stringent legal environment, are more likely to assure the reports. Conclusions on the relationship between the legal environment in which the company operates, and its demand for assurance we see in the work of Kolk \& Perego (2010).

These authors' groups proved another important feature - there is a connection between the size of the company and the choice of the provider of assurance: larger companies choose well-known audit firms, (Simnett et al., 2009; Kolk and Perego, 2010). According to Perego (2009) companies from countries with a weak legal system are more prone to choosing large firms, as a provider of audit assurance.

In a later work of Kolk and Perego (2012) on the example of MNE from Global 250 list it is shown, how the use of accounting standards by providers affects the quality of SR assurance.

O'Dwyer, Owen, and Uneman (2011) demonstrated the relationship between the process of legitimation of the largest companies - providers of SR assurance and generation of assurance reports. Moreover, the authors considered legitimacy in three dimensions - pragmatic, moral and cognitive.

The relationship between corporate governance mechanisms and institutional ownership, managerial ownership, independent commissioners, audit committee and the quality of public accounting firm towards the integrity of financial statements was investigate by Savitri (2016).

The analysis of feedbacks between the auditor assurance and volume of information disclosure is presented in the work of Faisal and Rusmin (2012). The authors proved the hypothesis that firms with an assurance statement in their sustainability reports will provide higher voluntary disclosure, than firms with no assurance statement. An attempt to create a basis for SR audit reporting, based on Grounded Theory, was performed by Morimoto et al. (2004). Detailed examination of one of the key standards of SR assurance is made in the work by Simnett (2012).

Some evidence on SR investigation in banking sector provide Smit and Zyl (2016). Corporate governance disclosure in bank's annual reporting was appraised by Dzomira (2015).
The issue of ensuring of legitimacy and legal liability of companies through SR mechanisms and its assurance is widely reflected in academic circles. However, the issue of achieving legitimacy by Ukrainian companies through the publication of SR with relevant assurance did not get a significant spread.

A significant impetus to the standardization and spread of procedures for SR audit assurance, in addition to theoretical studies and their practical relevance, are provided by regulatory initiatives, both governmental and intergovernmental organizations and exchanges.

Along with the EU Directive 2014/95 / EU "On Disclosure of Non-Financial and Diversity Information" (Article 19a, Paragraph 6 of the Directive 2014/95 / EU on Disclosure of Non-Financial and Diversity Information, issued in 2014 by the European Union (EU)), which justifies the provision of non-financial reporting assurance by large companies, starting from the 2017 fiscal year, there are a number of such initiatives:

- The Guidelines of OECD for Multinational Enterprises (Title III, Paragraph 3 of the Guidelines for Multinational Enterprises, issued in 2011 by the Organisation for Economic Co-operation and Development (OECD)), which establishes the need for an annual audit by a qualified auditor for both financial and non-financial reporting.

- Decree 2012-557 on obligations regarding transparency on social and environmental disclosure by companies, issued in 2012 by the French Government Decree 2012-557 on obligations regarding transparency on social and environmental disclosure by companies, issued in 2012 by the French Government, which obliges to include information on verification of social and environmental aspects of SR as a part of the annual report of large and listed companies.

- Guidelines for external reporting by state-owned companies, issued in 2007 by the Swedish Government, which establishes the need for mandatory audit SR assurance for public companies, compiled by the principles of GRI - G 3 .

- B-Corp Legislation Assessment of Nonfinancial Information against a «Third Party Standard» for Companies under The Statute of Benefit Corporation, issued by US states, which sets the need for independent third party assessment of social and environmental information of B-Corp companies;

- Project of corporate law on social responsibility (Argentina, 2015) (Ley de Responsibilidad Social Empresaria (Proyecto), issued in 2015 by the Argentinean Government), which establishes the need for mandatory independent assurance by provider of audit services of SR reporting for companies of public or mixed ownership, private companies participating in public tenders and voluntary assurance for other companies. 
- Corporate Governance Code King III, issued in 2010 by the Institute of Directors in Southern Africa (IoDSA)), which defines mandatory assurance of integrated reporting for companies that are listed on Johannesburg Stock Exchange.

- Corporation Rules Governing the Preparation and Filing of Corporate Social Responsibility Reports by TWSE Listed Companies, issued in 2015 by the Taiwan Stock Exchange, establishing the need for external SR assurance, prepared in accordance with relevant standards GRI by listed companies of certain sectors.

Requirements and regulations for implementation of audit procedures during the SR assurance are contained in some national auditing standards, including: Practical Guidelines for the Assurance of Sustainability Information, 2007 Japanese Association of Assurance Organizations for Sustainability, which is based on the ISAE 3000, Standard COS $3810 \mathrm{~N}$ Assurance Engagements relating to Sustainability Reports, 2007, issued by The Royal Dutch Institute for Registered Accountants (NIVRA) Netherlands, which generally corresponds to ISAE 3000 and incorporates the principles of GRI; ICJCE Action Guide, 2008, developed by the Institute of Chartered Accountants of Spain, Spain; Standard RevR 6 Independent Assurance of Separate Voluntary Sustainability reports, 2004, issued by The Swedish Institute for the Accountancy Profession, Sweden, based on the above mentioned ISAE 3000.

It should also be noted that in the GRI Guidelines G4 the use of external SR assurance is recommended, but is not mandatory with reference to the mentioned management.

Thus, legal regulation of SR assurance becomes widely spread not only as a voluntary initiative of companies to achieve legitimacy and implementation of legal liability as part of CSR, but is postulated by legislation, in auditing standards at international and national level and in relevant stock exchange rules. Instead, the practice of standardization and regulation of audit assurance in Ukraine requires a more thorough examination in the light of compliance of used audit approaches with international ones, especially with European initiatives to promote non-financial reporting and assuring it.

\section{Practical insights}

The selection of data for the study was dictated by the most complete presentation of the reports on sustainable development of Ukrainian companies. The review of the most famous base of CSR reporting in the world - Corporateregister containing 81,840 samples gave negative results. In contrast to international practice (Fig. 1), where every 5 th report filled with the external independent assurance the disclosure of SR by Ukrainian companies has not yet become the norm (Fig. 2).

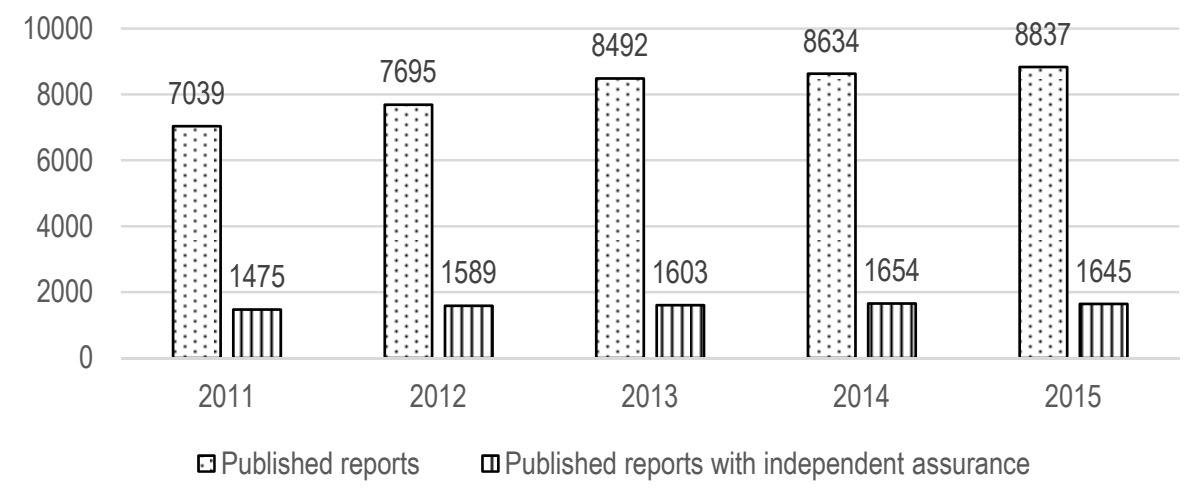

Fig. 1. State of publishing CSR reporting and their assurance in the world in 2011-2015 according Corporateregister.com

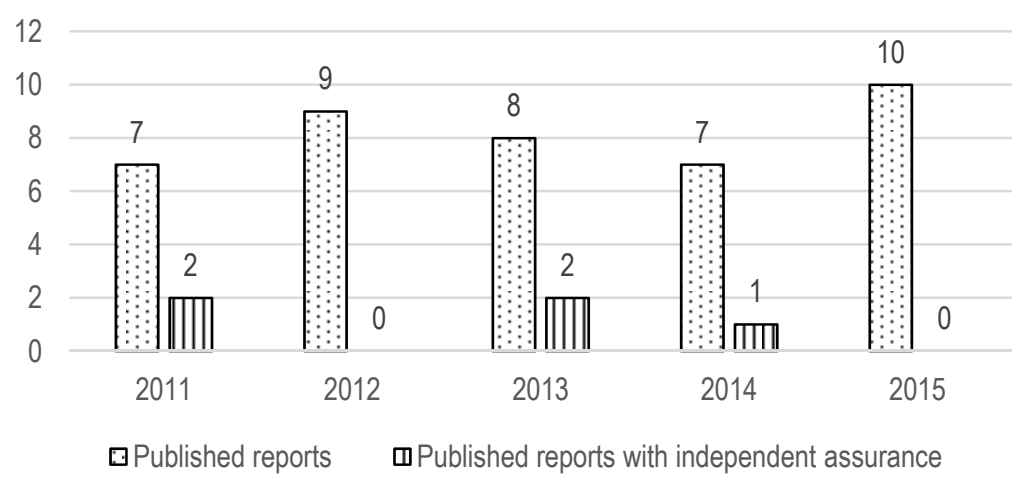

Fig. 2. State of publishing CSR reporting and their assurance in Ukraine in 2011-2015 according Corporateregister.com 
Given such low levels of publication in Corporateregister.com a search for SR of Ukrainian companies in other databases was made, in particular in GRI base, which by meaningful features is aimed at disclosure of achieving progress in SDG 12.6.

Moreover, among the 37,157 represented by 10 , 101 organizations reports in this base, 25,151 samples are drawn by GRI approaches. It should be noted that today the conceptual framework and GRI standards are the most common volunteer guideline for formation and submission of SR in the world (according to the KPMG 2015 in 2015 more than $60 \%$ of reporting on CSR bodies in surveyed 45 countries refer in their reports to this organization; separate reports on CSR and SR are based on the GRI in $72 \%$ of cases, and this foundation is used by $74 \%$ of the world's largest companies in terms of revenue among G250).

The number of Ukrainian companies presented in this base is relatively small - 21 companies with 47 reports, covering the reporting year periods of 2005-2014. Considering that today it is the most complete database for Ukrainian companies, which contains information about the level of confidence in SR, its continuous verification and content analysis was held. The main parameters of verified reports of Ukrainian companies are presented in Appendix (fragment of current reporting base).
Using methods of comparative analysis in the context of the theory of legitimacy, we hold comparison of global and national experience of independent assurance on SR in such areas, as the volume and dynamics of the verified according to relevant standards reports; status of the SR assurance service provider; scale of audit study of reports and actual standards, on which the assurance procedures are based.

General dynamics to provide evidence for SR for the largest companies in the world according to the level of income, as well as among the national leaders of business, is characterized by constantly increasing trend (Fig. 3), which suggests the standardization of practices of SR verification in the world to ensure the legitimacy of companies. Among the countries, where SR is mostly checked by the independent auditor in 2015 the following countries should be called: France $(96 \%$ of all corporate SR reports), South Korea (86\%), Greece $(70 \%)$, Taiwan $(70 \%)$ and the UK (61\%). Such significant share of verified reports in these countries exist due to various reasons, from direct government requirements (France) and the requirements of supervisory institutions (Taiwan, United Kingdom) to voluntary initiatives of largest companies (Greece, South Korea).

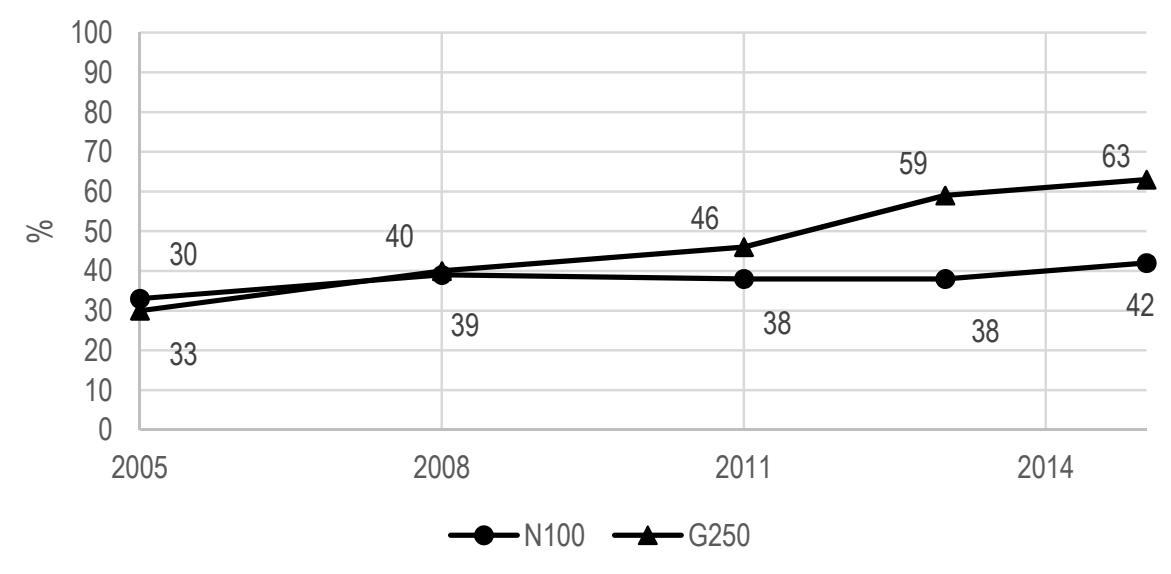

Fig. 3. Share of corporate reports with independent assurance of the biggest companies in the world in 2005-2015, composed from materials of KPMG (Currents of change The KPMG Survey of Corporate Responsibility Reporting 2015.)

However, only a quarter of Ukrainian companies, which supply SR in various formats $(25.5 \%$ of total reports) resorted to its verification during 20052014. Describing a sample of domestic companies, supplying SR with independent assurance, it should be noted that these are mostly large or multinational companies (MNE), representing the sectors of metal production (ArcelorMittal Ukraine, Dneprospetsstal, Metinvest), mining industry (DTEK), agribusiness (Kernel), manufacture of food products and beverages (Obolon), financial services (Platinum Bank) and other sectors (SCM).
Regarding the status of the service provider of SR proof, it should be noted that among the reports of the 100 largest companies in 45 countries of the world in $201564 \%$ of them are verified by the companies that provide professional accounting and auditing services, especially by Big 4 companies. A similar proportion of reports $-65 \%$ of the total number of reports on CSR havean independent assurance among the 250 largest companies in the world.

Assurance of SR of Ukrainian companies is also carried out mainly by companies, providing professional services, including a representative of Big 4 - market 
share in assuring reports of the largest representatives of heavy industry (ArcelorMittal Ukraine, Metinvest, SCM, DTEK) $-58 \%$ and other representatives of audit companies of mid-tier - BDO (Obolon) and BakerTilly Ukraine (Kernel), which is consistent with the findings, obtained by Perego (2009).

There is also such a form of assurance on SR as a public assurance - reports of Dneprospetsstal and Platinum Bank are certified by the Centre for collaboration between business and society. In the first case the official report is given, in the second - the expert opinion with the conclusion on compliance with standards of non-financial reporting preparation is provided: "The report contains in general meaningful information, covers key areas of responsible business practices, discloses information about the company in these areas with sufficient completeness and meets recognized international standards of non-financial reporting preparation" (Platinum Bank, 2011).

However, reports on sustainable development of the companies that provide professional services, including KPMG and E\&Y, which are also presented in the GRI base, do not have independent external assurance. Only the report on sustainable development of E\&Y has a link to an internal audit, which is consistent with generally accepted practice of SR assurance by internal auditors.

As to the extent of the auditor's investigation of corporate reporting on CSR, it should be noted that a half of the reports are verified completely, $34 \%$ of provided external evidences are related to specific indicators of sustainable development, $11 \%$ - relating to the combination of individual chapters and indicators, and 5\% - related to specific chapters of the report (Currents of change The KPMG Survey of Corporate Responsibility Reporting, 2015).

Verification of reports of Ukrainian companies in $67 \%$ of cases concerns separate chapters and sections of the report, however, there are such special acknowledgments as verification of DTEK report its report on sustainable development for 2009 , social report for 2007 are completely assured as well as the checking of the annual report of Kernel, where the object of the study were separate chapters on sustainable development.

As for the legitimacy of the applicable standards of audit SR assurance for Ukrainian companies the following information should be noted. Along with a significant number of standards of international governmental and non-governmental organizations (EU Directive on non-financial reporting, UN Global Compact principles, ISO 26000, OECD Guidelines for Multinational Enterprises, GRI Standards) and regulatory requirements of unions of supranational institutional structures (Group Friends of Paragraph 47 SDG Compass and the 12.6 tracker - general practice of SR disclosure, Sustainable Stock Exchanges Initiative,
World Federation of Exchanges, The United Nationssupported Principles for responsible investment (PRI) Reporting Framework - economic dimensions of sustainable development and responsible investment; The International Integrated Reporting Council (IIRC), The Sustainability Accounting Standards Board (SASB) developing standards in the field of integrated reporting and SR; Carbon Disclosure Project (CDP), Greenhouse Gas Protocol (GHG Protocol) Corporate Standard, CDSB (Climate Disclosure Standards Board), EMAS - the environmental dimensions of sustainable development; International Labor Organization (ILO) Tripartite declaration of principles concerning multinational enterprises and social policy, UN Guiding Principles on Business and Human Rights, OHSAS 18001: 2007 and SA 8000: 2001 Social Accountability, ISO SR 26000: 2011 "Social responsibility of organizations. Requirements Social dimension of sustainable development" to report in the area of sustainable development there are only two most recognized standards of assurance, validation and verification of SR (ISAE) 3000, Assurance Engagements other than Audits or Reviews of Historical Financial Information was developed by the International Auditing and Assurance Standards Board (IAASB) of the International Federation of Accountants (IFAC) and the AA1000 Assurance Standard (AA1000AS), 2008, issued by the UK-based Accountability.

Among the Ukrainian companies during external SR assurance ISAE 3000 "Assurance tasks other than audit or review of historical financial information" compiled by IFAC is most common. Among the standards (in $75 \%$ of cases assured reports), regulating the accounting disclosure, the GRI standard is most widely used $(60 \%$ of the aggregate number of investigated reports), and among the standards that define the content side of CSR companies - the report on progress towards the principles of the Global Compact (83\% of the aggregate number of investigated reports).

It should be noted that the standard AA1000 is not used by studied Ukrainian companies at all, which, in our opinion, is due to the relatively low level of SR orientation to the needs of stakeholders and level of the spread of stakeholder management model and traditions of a national accounting system formation that is poorly oriented to satisfy information requests of stakeholders. Disclosure of stakeholders' views and their compliance with the request for information are contained in 11 reports (23\%) of studied ones.

Widely used ISAE 3000 "Assurance tasks other than audit or review of historical financial information" as the basis for SR verification of Ukrainian companies is positioned according to all the studied reports by its legal status as a national (general) legislation. The said status is conditioned by separate Decisions of the Audit Chamber of Ukraine. Fundamental ones among them are the Decisions of the Audit Chamber of Ukraine of 18.04.2003 № 122/2 
auditing standards, by which international standards of quality control, audits, reviews, other assurance and related IFAC services are adopted as national auditing standards and a number of decisions, by which editions of these standards are updated in national practice in response to amendments to them.

Among them the following ones should be named: ACU Decision of 30.11.2006 № 168/7 “On International Auditing Standards use, edition of the $2006^{\text {th }}$ year”, ACU Decisions of 31.03.2011 № 229/7 “On the application of auditing standards", ACU Decision of 27.02.2014 number $290 / 7$ "On the application of auditing standards and ethics", ACU Decision of 24.12.2014 № 304/1 "On the application of auditing standards" and the ACU Decision of 29.12.2015 № 320/1 “On the application of auditing standards". The latter sets the voluntary application by audit firms (auditors) of International standards for Quality Control, Auditing, Review, Other Assurance and Related Services (edition of the 2014 year), when performing tasks in the period from the date of their promulgation.

The above mentioned decisions in the context of the application of ISAE 3000 "Assurance tasks other than audit or review of historical financial information" and ISAE 3410 "Assurance on emissions of greenhouse gases (GHGs) "in acknowledgment of the SR of Ukrainian companies and other auditing standards provide a legal collision - when the regulations of professional regulatory body establishes a special procedure for the application of standards of international non-governmental organizations. Thus, the Article 6 of the Law of Ukraine «On Auditing» determines that auditing standards are adopted on the basis of auditing standards and ethics of the International Federation of Accountants with the requirements of this law and other legal acts. However, the direct requirements of the IFAC standards, albeit voluntarily to perform the procedure, which is typical for the norms of "soft" law, by the decision of ACU have been moved in translated form without proper implementation and clarification to national soil.

Despite the existence of discussions on the classification of international auditing IFAC standards as "soft" or "hard" norms, they have some degree of mandatory status in view of the theory of legitimacy of companies, and legal aspect of CSR, are designed to unify the approach to perform auditing tasks internationally and to promote a high level of professionalism of auditors for ensuring quality audit services.

According to the Constitution and the Regulations of the IFAC, International Auditing Standards developed by the Council of International Standards on Auditing and Assurance of IFAC are mandatory for full members of the organization and by their legal nature have to harmonize the regulation of auditing at the international level by each individual standard, including SR assurance, but not regulate the procedure for auditing in specific countries. Moreover, they serve as benchmarks for the development of national standards.

This practice of the standardization of audit assurance on the basis of adoption of appropriate national standards that take into account the IFAC rules is characteristic for Japan (Practical Guidelines for the Assurance of Sustainability Information), the Netherlands (Standard COS 3810N Assurance Engagements relating to Sustainability Reports), Spain (ICJCE Action Guide, 2008). Developed by the Institute of Chartered Accountants of Spain), Sweden (Standard RevR 6 Independent Assurance of Separate Voluntary Sustainability reports).

Thus the use of priority ISAE 3000 "Assurance tasks other than audit or review of historical financial information", ISAE 3410 "Assurance on emissions of greenhouse gases (GHGs)" requires clarification of their legal status and integration into the national accounting system for creating an effective framework for SR assurance in Ukraine, raising its credibility and legitimacy of Ukrainian companies.

\section{Conclusions and policy implication}

The issues of SR assurance use as a means to promote the legitimacy of companies are broadly covered in academic circles. Moreover, the focus of international governmental and non-governmental organizations that are relevant to the SR is also centered on the feasibility of providing such evidence.

The comparison of international practice in SR assurance with Ukrainian realities, grounded on a report database of Ukrainian GRI companies for the years of 2005-2014 on the criteria of volume, the status of the provider of assurance, scale of the study, showed the initial stage of its development. The pioneers in drawing verified SR are the largest and multinational companies, representing sectors of metal processing, food and beverage manufacture, mining industry.

It should be noted that on the market of SR assurance for Ukrainian companies there are professional providers - large companies providing accounting and auditing services, especially Big 4 companies.

In contrast to international practice, SR of Ukrainian companies are partially verified; the attention of external auditors is focused on the individual chapters, devoted to dimensions of sustainable development, which may indicate a fragmentation in the presentation of CSR of Ukrainian companies.

The conclusion about the mismatch in scale, quantity and diversity of provided SR evidence of various forms of Ukrainian companies with international trends due to the initial stage of the development of CSR initiatives, its reflection in the statements and assurance in the interest of stakeholders in Ukraine, was also carried out during the practical part of the study. 
The analysis of the current state of SR audit assurance of Ukrainian companies as the basis of their legitimacy and problematic aspects of the legal status of standards for such provision in Ukraine, suggests the need to strengthen the legislative initiatives in the field of regulation of the manner of disclosure and verification of information on CSR in SR in general in order to achieve harmonization with the relevant EU Directive, and clear definition of the status of International standards on quality control, auditing, review, assurance and related services for this purpose in particular.

The study above enables us to confirm the conclusion, reached in the work by Perego (2009), as for the recognition of large firms as a provider of assurance in countries with weak legal environment.

In this context, the issues of legal status of SR assurance standards of Ukrainian companies in order to ensure their legitimacy, lie in providing by the Audit Chamber of Ukraine the clarification and comments in the form of Regulations on national audit practice of auditing tasks on assurance of environmental, social and other information contained in the SR of Ukrainian companies, as well as guidelines for the application of ISAE 3000 and a separate standard ISAE 3410.

\section{References}

1. Adams, C.A., \& Evans, R. (2004). Accountability, completeness, credibility and the audit expectations gap. Journal of Corporate Citizenship, 14, 97-115.

2. Adams, C.A. (2004). The ethical, social and environmental reporting - performance portrayal gap. Accounting, Auditing and Accountability Journal, 17 (5), 731-757.

3. Davis, K. (1973). The case for and against business assumpti on of social responsibilities. Academy of Managementlournal, 16, pp. 312-322.

4. Deegan, C. (2002). The legitimizing effect of social and environmental disclosures - a theoretical foundation, Accounting, Auditing, \& Accountability Journal, 15 (3), 282-311.

5. Deegan, C., Cooper, B.J., \& Shelly, M. (2006). An investingation of TBL report assurance statements: UK and European evidence. Managerial Auditing Journal, 21 (4), 329-371.

6. Dzomira S. (2015). Corporate governance appraisal: annual reports disclosure by commercial banks in Zimbabwe. Banks and Bank Systems, 4 (10), 32-40. Available at: https://businessperspectives.org/media/zoo/applications/publishing/templates/article/assets/js/pdfjs/web/viewer.ph p?file=/pdfproxy.php?item id:7031.

7. Faisal Tower, Greg; and Rusmin, Rusmin. (2012). Legitimising Corporate Sustainability Reporting Throughout the World, Australasian Accounting, Business and Finance Journal, 6 (2), 19-34. Retrieved from http://ro.uow.edu.au/aabfj/vol6/iss $2 / 3$

8. Kolk, A., \& Perego, P. (2010). Determinants of the Adoption of Sustainability Assurance Statements: An International Investigation, Business Strategy and the Environment, 19, 182-198

9. Mohamed A. Omran Theoretical Perspectives on Corporate Social Responsibility Disclosure: A Critical Review. International Journal of Accounting and Financial Reporting, ISSN 2162-30822015, 5(2).

10. Morimoto, Risako and Ash, Johnand Hope, Christopher. (2004). Corporate Social Responsibility Audit: From The oryto Practice. University of Cambridge, Judge Institute of Management Working Paper No. 14/2004. Retrieved from https://ssrn.com/abstract $=67014$

11. O'Dwyer, Brendan and Owen, David and Uneman, Jeffrey, Seeking Legitimacy for New Assurance Forms: Th Case of Assurance on Sustainability Reporting (January 18, 2011). Accounting, Organizations and Society, Forthcoming. Retrieved from https://ssrn.com/abstract=1742822.

12. Perego, P.M. (2009). Causes and consequences of choosing different assurance providers: An international study of sustainability reporting, International Journalof Management, 26(3), 412-425.

13. Perego, P., \& Kolk, A. (2012). Multinationals' Accountability on Sustainability: The Evolution of Third-party Assurance of Sustainability Reports, Journal of Business Ethics, 110, 173-190.

14. Preston, L.E., \& Post, J.E. (1975). Private management and public policy: The principle of public responsibility. Englewood Cliffs, NJ: Prentice-Hall.

15. Savitri, E. (2016). Coorporate governance mechanism and the moderating effect of independency on the integrity of financial reporting. Investment Management and Financial Innovations, 4 (13), 68-74. Available at: https://businessperspectives.org/media/zoo/applications/publishing/templates/article/assets/js/pdfjs/web/viewer.ph p?file=/pdfproxy.php?item_id:7968.

16. Simnett, R. (2012). Assurance of sustainability reports. Revision of ISAE 3000 and associated research opportunities, Sustainability Accounting, Management and Policy Journal, 3(1), 89-98.

17. Simnett, R., Vanstraelen, A., \& Chua, W.F. (2009). Assurance on sustain ability reports: An international comparison, Accounting Review, 84 (3), 937-967.

18. Smit, A. M., Zyl, J. (2016). Investigating the extent of sustainability reporting in the banking industry. Banks and Bank Systems, $11 \quad$ (4), 71-81. Available at: https://businessperspectives.org/media/zoo/applications/publishing/templates/article/assets/js/pdfjs/web/viewer.ph p?file=/pdfproxy.php?item_id:7999.

19. Wood, D.J. Corporate Social Performance Revisited Donna J. Wood. The Academy of Management Review, 16 (4). (Oct., 1991), 691-718.

20. Zorio, A., García-Benau, M.A., \& Sierra, L. (2013). Sustainability Development and the Quality of Assurance Reports: Empirical Evidence, Business Strategy and the Environment, 22, 484-500. 
Table 1. The main parameters of verified reports of Ukrainian companies

\begin{tabular}{|c|c|c|c|c|c|c|c|c|c|c|c|c|c|c|c|c|c|}
\hline Company & $\begin{array}{l}\text { Repor- } \\
\text { ting } \\
\text { period }\end{array}$ & Sector & Size & $\begin{array}{c}\text { Repor- } \\
\text { ting } \\
\text { stan- } \\
\text { dard } \\
\end{array}$ & $\begin{array}{l}\text { Adherence } \\
\text { Level }\end{array}$ & $\begin{array}{c}\text { CSR } \\
\text { Statndard }\end{array}$ & Report title & $\begin{array}{l}\text { Integra- } \\
\text { ted }\end{array}$ & $\begin{array}{l}\text { StakeholderPanel/ } \\
\text { Expert Opinion }\end{array}$ & $\begin{array}{l}\text { Externalassu } \\
\text { rance }\end{array}$ & $\begin{array}{l}\text { Type of } \\
\text { Assurance } \\
\text { Provider }\end{array}$ & $\begin{array}{c}\text { Assurance } \\
\text { Provider }\end{array}$ & $\begin{array}{l}\text { Assurance } \\
\text { Standard }\end{array}$ & $\begin{array}{l}\text { Assurance } \\
\text { Scope }\end{array}$ & $\begin{array}{c}\text { Level } \\
\text { ofAssurance }\end{array}$ & Standartstaus & ESG \\
\hline ArcelorMittalUkraine & 2013 & MetalsProducts & MNE & $\begin{array}{c}\text { GRI- } \\
\text { G3 }\end{array}$ & $B+$ & UNGC & CSR Report & No & No & Yes & Accountant & $E \& Y$ & ISAE3000 & $\begin{array}{l}\text { Specified } \\
\text { section(s) }\end{array}$ & Limited/moderate & $\begin{array}{l}\text { National } \\
\text { (general) }\end{array}$ & ESG \\
\hline ArcelorMittalUkraine & 2012 & MetalsProducts & MNE & $\begin{array}{c}\text { GRI- } \\
\text { G3 }\end{array}$ & $B+$ & UNGC & $\begin{array}{l}\text { SocialRe- } \\
\text { port }\end{array}$ & No & No & Yes & Accountant & $E \& Y$ & ISAE3000 & $\begin{array}{l}\text { Specified } \\
\text { section(s) }\end{array}$ & Not specified & $\begin{array}{l}\text { National } \\
\text { (general) }\end{array}$ & ESG \\
\hline ArcelorMittalUkraine & 2011 & MetalsProducts & MNE & $\begin{array}{c}\text { GRI- } \\
\text { G3 }\end{array}$ & $\mathrm{B}^{+}$ & UNGC & $\begin{array}{c}\text { SocialRe- } \\
\text { port }\end{array}$ & No & No & Yes & Accountant & $E \& Y$ & ISAE3000 & $\begin{array}{l}\text { Specified } \\
\text { section(s) }\end{array}$ & Not specified & $\begin{array}{l}\text { National } \\
\text { (general) }\end{array}$ & \\
\hline Dneprospetsstal & 2012 & MetalsProducts & Large & $\begin{array}{c}\text { GRI- } \\
\text { G3 }\end{array}$ & $C+$ & UNGC & CSR Report & No & Yes & Yes & $\begin{array}{l}\text { Small } \\
\text { consultancy/ } \\
\text { boutique } \\
\text { firm }\end{array}$ & 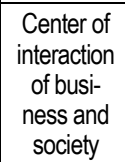 & $\begin{array}{c}\text { Not } \\
\text { specified }\end{array}$ & Notspecified & Not specified & $\begin{array}{l}\text { Not } \\
\text { applicable }\end{array}$ & ESG \\
\hline DTEK & 2009 & Mining & Large & $\begin{array}{c}\text { GRI- } \\
\text { G3 }\end{array}$ & $B+$ & UNGC & $\begin{array}{c}\text { Sustainability } \\
\text { report }\end{array}$ & No & Yes & Yes & Accountant & $E \& Y$ & Notspecified & Entire report & Not specified & $\begin{array}{l}\text { Not } \\
\text { applicable }\end{array}$ & $S$ \\
\hline DTEK & 2007 & Mining & Large & $\begin{array}{c}\text { GRI- } \\
\text { G3 }\end{array}$ & $C+$ & UNGC & Social report & No & no & Yes & Accountant & $E \& Y$ & ISAE 3000 & Entire report & Not specified & $\begin{array}{l}\text { Not } \\
\text { applicable }\end{array}$ & $s$ \\
\hline Kernel & 2014 & $\begin{array}{l}\text { Agriculture Food } \\
\text { Processing }\end{array}$ & Large & $\begin{array}{c}\text { GRI- } \\
\text { G4 }\end{array}$ & $\begin{array}{l}\text { Inaccordance } \\
\text { - Core }\end{array}$ & $\begin{array}{c}\text { Not } \\
\text { specified }\end{array}$ & Annualreport & No & No & Yes & Accountant & \begin{tabular}{|c|} 
BAKER \\
TILLY \\
UKRAINE
\end{tabular} & ISAE 3000 & $\begin{array}{l}\text { Specified } \\
\text { section(s) }\end{array}$ & Not specified & $\begin{array}{l}\text { National } \\
\text { (general) }\end{array}$ & ESG \\
\hline Metinvest & 2012 & MetalsProducts & Large & $\begin{array}{c}\text { GRI- } \\
\text { G3 }\end{array}$ & C & UNGC & Socialreport & No & No & Yes & Accountant & $E \& Y$ & ISAE3000 & $\begin{array}{l}\text { Specified } \\
\text { section(s) }\end{array}$ & Reasonable/high & $\begin{array}{l}\text { National } \\
\text { (general) }\end{array}$ & ESG \\
\hline Obolon & 2013 & $\begin{array}{l}\text { Food and } \\
\text { Beverage } \\
\text { Products }\end{array}$ & Large & $\begin{array}{c}\text { GRI- } \\
\text { G3 }\end{array}$ & $B+$ & UNGC & $\begin{array}{l}\text { Sustainability } \\
\text { report }\end{array}$ & No & No & Yes & Accountant & $\mathrm{BDO}$ & ISAE3000 & $\begin{array}{l}\text { Specified } \\
\text { section(s) }\end{array}$ & Not specified & $\begin{array}{l}\text { National } \\
\text { (general) }\end{array}$ & ESG \\
\hline Obolon & $\begin{array}{l}2011- \\
2012\end{array}$ & $\begin{array}{l}\text { Food and } \\
\text { Beverage } \\
\text { Products }\end{array}$ & Large & $\begin{array}{l}\mathrm{GRI}- \\
\mathrm{G} 3\end{array}$ & $B+$ & UNGC & $\begin{array}{l}\text { Sustainability } \\
\text { report }\end{array}$ & No & No & Yes & Accountant & $\mathrm{BDO}$ & ISAE3000 & $\begin{array}{l}\text { Specified } \\
\text { section(s) }\end{array}$ & Not specified & $\begin{array}{l}\text { National } \\
\text { (general) }\end{array}$ & ESG \\
\hline Platinum Bank & 2010 & FinancialSenvices & Large & $\begin{array}{c}\text { GRI- } \\
\text { G3 }\end{array}$ & C & UNGC & $\begin{array}{l}\text { Sustainability } \\
\text { report }\end{array}$ & No & Yes & Yes & $\begin{array}{l}\text { Small } \\
\text { consultancy/ } \\
\text { boutique } \\
\text { firm }\end{array}$ & 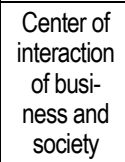 & $\begin{array}{c}\text { Not } \\
\text { specified }\end{array}$ & $\begin{array}{c}\text { Not } \\
\text { specified }\end{array}$ & Not specified & $\begin{array}{l}\text { Not } \\
\text { applicable }\end{array}$ & ESG \\
\hline SCM Group & 2012 & Other & MNE & $\begin{array}{c}\text { GRI- } \\
\text { G3 }\end{array}$ & $B+$ & UNGC & $\begin{array}{l}\text { Sustainability } \\
\text { report }\end{array}$ & No & No & Yes & Accountant & E\&Y & ISAE3000 & $\begin{array}{l}\text { Specified } \\
\text { section(s) }\end{array}$ & Limited/moderate & $\begin{array}{l}\text { National } \\
\text { (general) }\end{array}$ & ESG \\
\hline
\end{tabular}

